
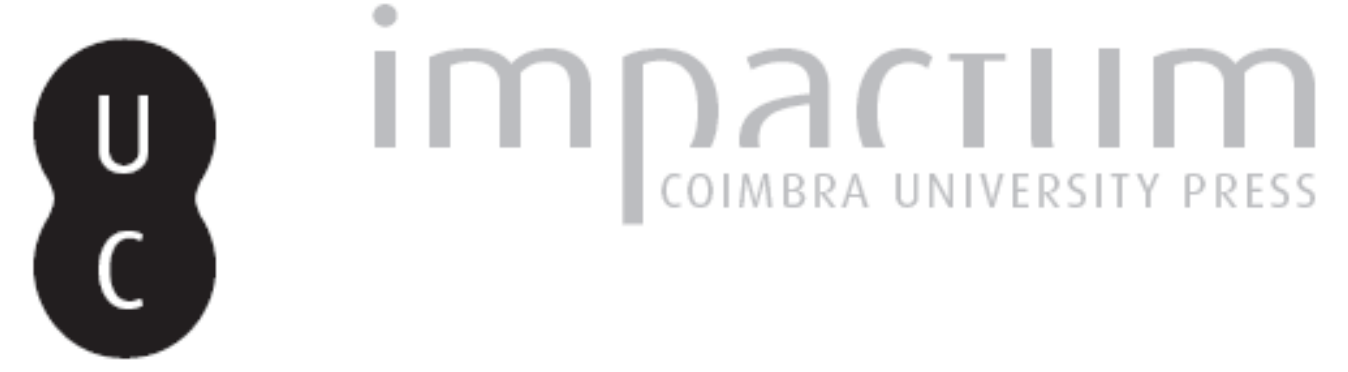

\title{
Memórias da Casa Pia das Convertidas: instituição, espaços e agentes face ao problema da prostituição em Lisboa (séculos XVI-XX)
}

Autor(es): $\quad$ Rijo, Delminda Miguéns

Publicado por: Imprensa da Universidade de Coimbra

URL persistente:

URI:http://hdl.handle.net/10316.2/43330

DOI:

DOI:https://doi.org/10.14195/1645-2259_17_6

Accessed : $\quad$ 26-Apr-2023 12:38:49

A navegação consulta e descarregamento dos títulos inseridos nas Bibliotecas Digitais UC Digitalis, UC Pombalina e UC Impactum, pressupõem a aceitação plena e sem reservas dos Termos e Condições de Uso destas Bibliotecas Digitais, disponíveis em https://digitalis.uc.pt/pt-pt/termos.

Conforme exposto nos referidos Termos e Condições de Uso, o descarregamento de títulos de acesso restrito requer uma licença válida de autorização devendo o utilizador aceder ao(s) documento(s) a partir de um endereço de IP da instituição detentora da supramencionada licença.

Ao utilizador é apenas permitido o descarregamento para uso pessoal, pelo que o emprego do(s) título(s) descarregado(s) para outro fim, designadamente comercial, carece de autorização do respetivo autor ou editor da obra.

Na medida em que todas as obras da UC Digitalis se encontram protegidas pelo Código do Direito de Autor e Direitos Conexos e demais legislação aplicável, toda a cópia, parcial ou total, deste documento, nos casos em que é legalmente admitida, deverá conter ou fazer-se acompanhar por este aviso.

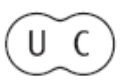




\title{
Memórias da Casa Pia das Convertidas. Instituição, Espaços e Agentes face ao Problema da Prostituição em Lisboa (Séculos XVI-XX) \\ Memories of Casa Pia das Convertidas of Lisbon. Institution, Houses and Agents (16 $6^{\text {th }}-20^{\text {th }}$ Centuries)
}

\author{
Delminda Miguéns Rujo \\ Investigadora Câmara Municipal de Lisboa \\ CITCEM - GHP \\ delminda.rijo@cm-lisboa.pt
}

Texto recebido em/Text submitted on: 22/11/2016

Texto aprovado em /Text approved on: 09/05/2017

Resumo: A reunião de fontes históricas documentais, algumas inéditas, sobre a Casa Pia das Convertidas de Lisboa, orientou-nos numa síntese sobre uma instituição que na sua génese se propôs retirar da sociedade e regenerar mulheres em situação de prostituição e de exclusão familiar e matrimonial, no decurso de um período que cobre toda a Idade Moderna e se prolongou até ao início do século XX.

Toda a narrativa é perpassada por temas como a fundação, os instituidores e as suas motivações, o impacto social, o quotidiano e o almejado "remédio de vida", expressando uma obra que, embora pré-existente à realização do Concilio de Trento, interpreta plenamente o espírito reformista daí saído.

Palavras-chave: Recolhimentos, Lisboa, Casa Pia das Convertidas.

Abstract: The meeting of historical documentary sources, some of them unpublished, on the "Casa Pia das Convertidas" in Lisbon, guided us in a synthesis about an institution that, in its genesis, was proposed to withdraw from society and regenerate women in situations of prostitution and family and marital exclusion, during a period that covers the entire Modern Age and continued until the beginning of the twentieth century.

The whole narrative is permeated by themes such as the foundation, the founders and their motivations, social impact, daily life and the desired "remedy of life", expressing a work that although pre-existent to the realization of the Council of Trent, fully interprets the reformist spirit that came out.

Keywords: Gatherings, Lisbon, House of Converted Women.

A reunião e análise de fontes históricas documentais sobre a Casa Pia das Convertidas de Lisboa, com destaque para o compromisso original que se considerava perdido ${ }^{1}$ e que identificámos no Arquivo Histórico da Santa Casa da

1 Cf. Maria Joana de Sousa Anjos Martins Subsídios para o Estudo da Assistência Social Portuguesa. Os Recolhimentos de Lisboa. 1543-1623. Dissertação para licenciatura em Ciências Históricas e Filosóficas, apresentada à Faculdade de Letras da Universidade de Lisboa, Lisboa, 1961, p.194. 
Misericórdia de Lisboa, corroboram e atualizam o conhecimento histórico sobre o quadro normativo primitivo e o funcionamento quotidiano daquele que terá sido um dos primeiros recolhimentos fundados em Portugal e domínios ultramarinos, destinado a mulheres convertidas ${ }^{2}$.

O propósito deste estudo, fundamentado no referido corpus documental, é desenvolvido em três partes:

Numa perspetiva preambular, contextualizar a fundação da Casa Pia das Convertidas de Lisboa, enquanto medida assistencial conjunta das autoridades régia, eclesiástica e iniciativa civil, face ao problema da prostituição na capital (séc. XVI-XVIII);

Contribuir para a interpretação das etapas da sua "biografia”, com enfoque no percurso institucional - fundação, agentes, objetivos;

Privilegiando o período entre os finais do séc. XVI e meados do séc. XVIII, perscrutar o quotidiano da Casa Pia das Convertidas dentro de portas, desde o ingresso até à reintegração da mulher na sociedade, relacionando-o pontualmente com Casas congéneres do espaço ibérico e outros recolhimentos de Lisboa $^{3}$.

I

Em 1543 foi instituída a Casa de Santa Marta em Roma, vocacionada para o acolhimento e recolocação no "bom caminho" de mulheres arrependidas. Adotou como modelo os recolhimentos para mulheres arrependidas já existentes em Castela (Coelho 2006:257). Nesse mesmo ano foi fundado em Lisboa o Mosteiro das Penitentes, perfilando os mesmos objetivos.

O modelo terá ampla difusão no movimento de Contra-Reforma iniciado no século XVI e que trará profundas mudanças à igreja e sociedade ocidental. Este irá também influenciar a própria prática assistencial ao fomentar a ação catequizadora contra o pecado, sobretudo o público, direcionando a ação da caridade para os mais vulneráveis ao mesmo - os pobres e as mulheres (Mestre e Loja 2004:192).

2 O primeiro recolhimento para mulheres penitentes foi o de Santa Marta, fundado em Évora c.1540, por iniciativa dos padres Gomes de Miranda e Luís de Melo. Outros exemplos de recolhimentos fundados para convertidas foram o de Santa Maria Madalena, em Goa, em 1609, o Recolhimento das Convertidas em Braga, em 1722, ou o Recolhimento de Mulheres Arrependidas de Igarassu, no Brasil, c. de 1735.

3 Já estudados no âmbito de projeto «Da Cidade Sacra à Cidade Laica. A extinção das ordens religiosas e as dinâmicas de transformação urbana na Lisboa do século XIX» (PTDC/CPC-HAT/4703/2012) do Instituto de História da Arte (FCSH/NOVA), em parceria com a Câmara Municipal de Lisboa, a Direcção-Geral de Arquivos e a Fundação da Faculdade de Ciências e Tecnologia (FCT/NOVA) e financiado pela Fundação para a Ciência e Tecnologia. 
O alinhamento da pluralidade assistencial do Estado, da Igreja, de reis e poderosos na aplicação dos seus bens de alma e fundos monetários e patrimoniais, convergiu com algumas das determinações do Concílio de Trento, nomeadamente sobre a mulher e o seu papel na sociedade. De facto, a articulação da honra e da virtude feminina com a valorização do casamento, da família e da igreja (Coates 1998:218) mobilizaram a aplicação de muitos bens na fundação e manutenção de estruturas especializadas no afastamento da mulher dos perigos do mundo - os recolhimentos femininos.

Estes surgiram por toda a Europa, incluindo Portugal e alguns territórios ultramarinos, diferenciando-se de outros fundados em períodos anteriores e que promoviam o afastamento do século por vocação religiosa e não com objetivos de controlo social. Uns estavam mais vocacionados para resguardo de órfãs, viúvas, desamparadas e depositadas e outros para mulheres "perdidas", normalmente votivos a Santa Maria Madalena (Lopes 2010:101).

Quando os primeiros decretos conciliares chegam a Portugal, c. 1550, no reinado de D. João III, referindo a mulher em disposições sobre a virtude feminina e o casamento, já funcionavam em Lisboa por iniciativa régia, pelo menos desde 1543, dois recolhimentos sob administração da confraria da Paixão de Cristo - o Mosteiro das Órfãs Honradas e o Mosteiro das Convertidas, promovendo o primeiro a vigilância e preservação da honra e virtude de jovens órfãs e o segundo a recuperação de mulheres de vida dissoluta ou em perigo de nela cair.

Estas iniciativas harmonizam-se com outro movimento, coetâneo, de reforma da moral sexual, caraterizado por novas atitudes em relação ao corpo e a novas regras de comportamento "invadindo o pudor e a castidade todas as áreas da vida quotidiana” (Grieco 1991:92).

Alteraram-se conceitos anteriormente aceites, nomeadamente em relação ao papel da prostituta. As relações sexuais fora do casamento deixaram de ser olhadas como uma necessidade natural dos homens, passando a ser vistas como luxúria e a prostituta, anteriormente tolerada e considerada como um freio à lascívia, passou a ser encarada como o verdadeiro agente do vício (Sobremazas 2006:17).

A sexualidade foi alvo de maior policiamento "tornando-se um dos fantasmas das autoridades civis e religiosas" (Grieco, 1991:92) e o contexto de crises de mortalidade quase contínuas e a conjuntura migratória dos Descobrimentos, com ausência dos homens das famílias, evidenciaram a necessidade de intervenção num numeroso grupo de mulheres desamparadas e muito expostas à prática da prostituição.

Lisboa era a capital e palco de grandes movimentações populacionais e como tal tinha grande oferta de serviços sexuais, tornando-se relevante para os diversos poderes, em prol do bem comum e anulação dos maus exemplos, a retirada destas mulheres das ruas (Araújo 2015:128). As fontes documentais 
eclesiásticas do séc. XVII atestam a dimensão do problema, sendo bem expressivos os números da Visitação do Arcebispado à freguesia do Loreto em 1628, a mesma onde se localizava a Casa Pia das Convertidas.

Excluindo outros indivíduos que dependiam da prostituição, como as alcoviteiras e alcoiceiras e alguns familiares, ou pessoas em relacionamentos ilegítimos que não configuravam casos de prostituição, mas frequentemente caiam nela, apurámos 75 mulheres denunciadas como devassas "de seu corpo" (AHPL, ms. 342 , fl. 252 a 338, 1628), referindo-se os relatos quer à prática individual, com ou sem consentimento familiar (do marido ou dos pais), e a grupos de mulheres que coabitavam no mesmo espaço.

Tratando-se de um pecado público, que colocava em causa a estabilidade social, estava sujeito à aplicação de uma pena, variável consoante a gravidade. Por não dispor de arruamentos próprios, a prostituição era proibida nesta freguesia. Estava previsto na lei de D. Sebastião, de 1570, que as "mulheres de fortuna" fossem remetidas para ruas próprias "por se evitarem os muitos inconvenientes que se seguem de viverem e morarem misticamente com outra gente" (cit. Aguiar 1947:466).

Na primeira metade do século XVII houve grande produção legislativa que visava combater, ou pelo menos conter, a prostituição: o Regimento dos Quadrilheiros (1603) ordenava aos oficiais de justiça a identificação de prostitutas por bairros e a sua participação às autoridades; o Regimento dos Corregedores e Juízes do Crime dos Bairros de Lisboa (1608) na realização de devassas semestrais às pessoas "que dão ou consentem alcouce em casa, ás mães que prostituem suas filhas" (idem, 467). As cortes régias (1624 e 1628) também debateram o assunto, recomendando a averiguação dos pecados públicos para o âmbito local dos corregedores.

A Casa Pia das Convertidas de Lisboa acolhia mulheres deste contexto social ou em perigo de nele cair - a mesma Visitação reporta 24 maridos ausentes em vários territórios ultramarinos (AHPL, ms. 342, fl. 252 a 338, 1628), um fator de degradação social dos agregados e de cujo meio familiar o recolhimento também recebia mulheres.

Perante a dimensão do flagelo, o recolhimento significava uma das possibilidades de reabilitação, numa sociedade em que a imagem da mulher pública adquiriu uma nova vertente, a da mulher pecadora que afetava a estabilidade social, mas que podia salvar-se através da redenção (Sobremazas 2006:17).

Entre meados do séc. XVI e finais do séc. XVIII foram fundados em Lisboa, por iniciativa de um ou mais benfeitores, cerca de 25 recolhimentos. Alguns perduraram apenas na memória, limitando-se a sua narrativa a uma notícia, um nome, ou um sítio. Dos restantes, os primeiros e melhor documentados e por isso mais estudados, de maior dimensão e provavelmente com maior relevância social, foram o Recolhimento das Órfãs do Castelo (1543), o Recolhimento das 
Donzelas Órfãs da Misericórdia (1594), o Recolhimento de Nossa Senhora do Amparo a São Cristóvão (1598) e o Recolhimento da Casa Pia das Convertidas $(1543, \text { c.1582 })^{4}$.

A tutela destas instituições foi exercida pelo Estado, através da Mesa da Consciência e Ordens, pela Igreja, ou por entidades por si designadas - Confrarias e Irmandades, de que a Misericórdia foi um exemplo relevante e que no Liberalismo recebeu a tutela e procedeu à reforma dos recolhimentos da capital. Ao contrário de outras cidades portuguesas, em Lisboa não encontramos a ação individual de um Bispo ou de outra dignidade da igreja, mas identificamos por exemplo, a fundação e administração por uma casa nobre, como o recolhimento do conde de S. Lourenço (ant. 1660), sobre o qual pouco se sabe.

A Casa Pia das Convertidas foi uma obra destinada à reforma e aproveitamento social de mulheres arrependidas, muito beneficiada com donativos e obrigações pias ${ }^{5}$, particularmente nos reinados de D. João III a D. Filipe II, cuja importância social ficou bem expressa no preâmbulo do Compromisso de 1592:

"Considerando isto algumas pessoas ilustres de sangue e de virtude pensando na elevação de tal obra e da graça de Deus e proveitosa à cidade de Lisboa [...] e nela há tantos e tão grandes mosteiros cheios de pessoas santas e religiosas que continuamente louvam e servem a Deus não convinha à sua grandeza faltar remédio para mulheres inda que pecadoras compadecendo-se com amor e caridade cristã do mau e perigoso estado das almas de algumas mulheres que por muitas ocasiões estão em pecado publico ofendendo a Deus com suas torpezas [...] ao menos achassem nesta cidade lugar seguro e aparelhado para delas se tirarem" (AHSCML, Compromisso da Administração da Casa da Piedade das Penitentes de Lisboa, s.p.).

II

Em 1551, Cristóvão Rodrigues de Oliveira nomeia D. João III como o fundador do Mosteiro das Penitentes da Paixão de Cristo, por conselho de letrados e do seu confessor, frei João Soares (cf. Oliveira 1939: 74-75).

O manuscrito "Memórias Históricas do Recolhimento das Convertidas" remete a iniciativa para a rainha consorte D. Catarina da Áustria, em apoio à

4 Todos eles já estudados por Reis, Maria de Fátima Dias, Poder Régio e tutela episcopal nas instituições de assistência na época moderna, os recolhimentos de Lisboa, 2004 e Maria Joana de Sousa Anjos Martins Subsídios para o Estudo da Assistência Social Portuguesa. Os Recolhimentos de Lisboa. 1543-1623. Dissertação para licenciatura em Ciências Históricas e Filosóficas, apresentada à Faculdade de Letras da Universidade de Lisboa, Lisboa, 1961.

5 Fernão Mendes Pinto, falecido a 8 de Julho de 1583, legou à Casa Pia das Penitentes o manuscrito original de A Peregrinação. A obra foi posteriormente organizada por frei Belchior de Faria, aprovada pela Inquisição em 1603 e impressa em 1614 pelo editor Craesbeeck. 
causa da negra Violante da Conceição, que começara por recolher prostitutas arrependidas num espaço que "tinha por detrás da Igreja de S. Cristóvão, de que trazia a chave, e ahi as sustentava com esmolas que tirava” (BNL, Memórias, fl. 180v). A "História Seráfica da Ordem dos Frades Menores na Província de Portugal" também refere Violante da Conceição, que indo em peregrinação a Roma, quis reproduzir em Lisboa o mosteiro de freiras da Ordem de Santo Agostinho, onde professavam mulheres penitentes (Esperança 1670: 519).

Frei Manuel da Esperança precisa a data da sua fundação, o dia 21 de Maio de 1543, com "trinta e três resolutas a mudar de vida", sob a regra de Santo Agostinho e o seu governo por freiras do mosteiro de Celas (Esperança 1670: 345). No ano seguinte, D. João III solicitou ao secretário em Roma, Baltasar de Faria, "graças e privilégios para um mosteiro de mulheres penitentes em que já então estavam recolhidas muitas" (apud Martins 1961:75), recebendo confirmação do papa Paulo III, em Março de 1544. Já então o recolhimento estava sob a tutela da Confraria da Paixão de N. Sr. Jesus Cristo (id. 1961:73), que também administrava o Mosteiro das Órfãs Honradas destinado a "filhas de ministros e fidalgas cujos pais houvessem falecido em serviço da coroa" (ANTT, Chancelaria D. João III, Liv. 5o, fl. 2).

A crise de subsistência de 1546 forçou a confraria a restituir a administração a D. João III (cf. ANTT, Corpo Cronológico, Mç. 78, Doc. 63), que a transferiu para o seu confessor e o governo interno para D. Filipa de Sousa, do convento de Chelas (História dos Mosteiros 1950:345).

Procurando-se um espaço mais adequado, o recolhimento foi transferido para a colina de Santana, junto da ermida da mesma evocação. A comunidade passou a dispor de cuidado espiritual apropriado e a assistir ao culto através de uma grade aberta na parede do edifício (BNL, Memórias, fl. 180v). Esta nova etapa é de continuidade, certificada pela carta régia de mercê de 1548 ao Mosteiro das Penitentes e Casa das Órfãs, "que se ora novamente hordenaram e fizeram na cidade de Lixboa” (ANTT, Chanc. D. João III, Livro 5º fl. 2). E ainda pela consignação de uma mercê de 60 homens para pedir esmola para as órfãs e convertidas (cf. ANTT, Chanc. D. João III, L. 35, fl. 30 v). Mercês que denotam o empenho régio na continuação de uma instituição que não só combatia a prostituição, como recuperava socialmente mulheres que eram válidas para outro projeto - pelo casamento, cujos dotes consistiam em cargos ultramarinos, contribuíam para o governo e povoamento dos territórios além-mar.

O mosteiro das Penitentes da Paixão de Cristo permanecerá nestes moldes cerca de duas décadas, convertendo-se em 1561 no mosteiro de Sant'Ana ${ }^{6}$ de religiosas da terceira Ordem de S. Francisco (Castro 1870:666). Apenas sete das

6 Foi elevado a convento de religiosas a 2 de Julho de 1562, sob a regra de Santa Clara, com obediência aos Prelados da Província Observante de Portugal. 
24 Penitentes da Paixão de Cristo ficaram no convento com intenção de professar (Conceição 1740:135).

Previamente a esta mudança, a rainha viúva D. Catarina pedira esclarecimentos sobre as Convertidas de Roma ao embaixador Lourenço Pires de Távora, que remeteu um caderno e cópia dos estatutos das Convertidas de Roma e a regra e traslado da bula das Convertidas de Castela (cf. ANTT, Corpo Cronológico, Parte I, Mç. 104, doc. 129). Dispunha-se talvez a dar continuidade à Casa, procurando-lhe uma regra mais adequada e eficaz face à realidade de Lisboa.

Só cerca de duas décadas depois haverá notícia de uma nova Casa de Convertidas em Lisboa e terá como principal figura o vigário geral dos religiosos capuchos de N. Sra. do Monte Carmelo, do convento de S. Filipe da Pampulha - frei Jerónimo Graciano da Madre de Deus.

Frei Belchior de Santa'Ana atribuiu-lhe a fundação e patrocínio da instituição, que manteria com as pregações e donativos que recolhia em diversas igrejas de Lisboa, como S. Roque ou S. Francisco da Cidade (cf. Sant'Ana 1657: 272-273). Para esta fase, aponta a "Memória Histórica" que o benfeitor seria um capitão castelhano, de apelido Cespedes, que conhecendo os recolhimentos de Castela e julgando-os adequados à realidade de Lisboa, teria pedido auxílio a frei Jerónimo Graciano. Talvez assim tivesse sido numa fase inicial, pois o patrocínio régio e o apoio de alguns nobres foram fundamentais para a concretização da obra, que permaneceu sob a proteção de corporações religiosas, primeiro de Agostinhos e depois de Jesuítas.

Segundo a "Memória Historica" a fundação da nova Casa Pia das Penitentes teria ocorrido em 1582, data em que o primeiro Provedor iniciou funções (cf. BNL, Memórias, fl. 210). O edifício primitivo estava localizado junto aos Fiéis de Deus, no Bairro Alto, e era contíguo à casa do benemérito capitão Cespedes. Mas a falta de condições para acolher uma comunidade de recolhidas ditou a transferência para outro edifício, localizado extramuros e entretanto desocupado pela congregação de religiosas flamengas. Ficava junto à ermida de N. Sra. da Glória, na atual avenida da Liberdade, onde possuía condições para a clausura roda, capela e portaria (id., fl. 184).

Frei Jerónimo Graciano terá fundado uma confraria, nomeou o Provedor, o meirinho mor D. Duarte de Castelo Branco e redigido um regulamento (Santa Ana 1657:273). A ação espiritual, as confissões e as eleições da mesa eram assistidas pelos religiosos de S. Filipe (id. 1657:273), ficando a partir de 1588 sob a direção espiritual dos padres da Companhia de Jesus.

A maior exposição a perigos e desordens - alguns foram mesmo relatados nas crónicas sobre as Convertidas - em mosteiros e recolhimentos femininos edificados fora dos núcleos urbanos, terá talvez motivado os jesuítas a procuraram-lhe um novo local e a integrá-lo no interior da cidade. O Prepósito de S. Roque, o padre Pedro da Fonseca, enviou a Roma, em Maio de 1587, uma carta 
na qual mencionava que a obra ainda não dispunha de casa e igreja próprias "que ya se le procura" (apud Martins 1961:83). A nova Casa seria formalizada a 28 de dezembro de 1587 e realizada uma procissão solene para o novo edifício no domingo, dia 19 de janeiro 7 .

$\mathrm{O}$ ato processional de transferência do recolhimento para o Loreto contou com a participação das mais ilustres figuras da cidade, o Provedor e nobreza de corte, os irmãos da mesa e religiosos dos principais conventos de Lisboa, criando um espetáculo público, ritualizado e encenado na rua para maior efeito pedagógico. Alertava para uma obra que combatia o persistente mal social da prostituição, reforçando ao mesmo tempo o sentido de devoção e de obediência à Igreja e ao Estado, pois conjugava o mundo secular e o mundo eclesiástico plenos de adornos, figuras e simbologia (cf. Furtado 1997:251).

A procissão contou com todos os elementos que fascinariam qualquer população na Idade Moderna: a representação das principais ordens monásticas, a presença do poder local e as protagonistas da obra pia - trinta e oito mulheres descalças com o hábito de S. Francisco - e por fim a participação direta da nobreza pela Regente, que com a porteira finalizavam o cortejo e "levavam diante de si duas meninas de nove anos que se tiraram a suas mães desordenadas para que se não perdessem" (BNL, Memórias, fl. 196v).

O percurso, criteriosamente delimitado, saiu das "ortas da Anunciada" e entrou no núcleo urbano pelas Portas de Santo Antão, entrando depois na grande praça da cidade, o Rossio. Foram aqui relatados simbólicos episódios de arrependimento e devoção, que se repetiram noutros locais, numa intensidade crescente, que exaltavam na assistência a valia social e religiosa da obra. Prosseguiu por várias ruas até chegar à Calcetaria, onde decorreu o auge da encenação, com a assistência do vice-rei das janelas do Paço da Ribeira. Chegou às Portas de Santa Catarina e entrou no Bairro Alto, cumprindo-se o objetivo pedagógico sobre a assistência.

A encenação prosseguiu no recolhimento, colocando-se as mulheres nas varandas "onde com os cortinados se cobriram do povo que ocupava o pátio" (id., fl. 197). Ao aparato da procissão seguiu-se o da decoração, preparada para impressionar os que observassem o interior do recolhimento, ornamentado com ricos tecidos de damasco e brocado e objetos simbólicos (id., fl. 197).

Os jesuítas envolveram-se na promoção da obra das Convertidas junto da população, sobretudo até às primeiras décadas do séc. XVII, conforme transparece a produção epistolar jesuítica, acompanhando situações de risco, promovendo ações de sensibilização e intervenção junto da população-alvo.

Creio que a data resulta de um erro de pena, devendo tratar-se de 1588, pois a carta de Pedro da Fonseca, de maio de 1587 , dava conta que procuravam uma casa próxima de S. Roque para as acolher. 
A exibição pública das recolhidas em certas cerimónias contribuía para a elevação social e religiosa da obra. Ocasionalmente participavam com cânticos em celebrações religiosas e nas exéquias dos benfeitores da Casa e noutros momentos simbólicos, como a colocação do Santíssimo Sacramento na igreja do recolhimento, em 1609, ato novamente revestido de aparato processional para deslumbre da assistência, o qual "[... ] já entrava na igreja das convertidas quando o Senhor estava ainda em S. Roque” (id., fl. 202). Também aqui se manifesta o favor régio pelo privilégio concedido da utilização dos símbolos reais - os panos de rás em prata e seda do rei e a missa celebrada com os cantores da capela real (id., $203 \mathrm{v}$ ).

O terramoto de 1755 destruiu o recolhimento e a igreja, obrigando as Convertidas a abrigarem-se em barracas num descampado da cidade, na Fonte Santa (Castro 1870:435). Todavia, sendo uma instituição sob proteção régia, foi arrendado um terreno para a construção de uma barraca mais apropriada e pedida uma planta a Eugénio dos Santos (aviso régio de 30 de julho de 1756). Foi enviada a 3 de Setembro de 1756 ao conde de Povolide, mas desconhece-se se a obra foi executada (cf. ANTT, Providências L e LI que se deram no terramoto, pág. 278-279).

Segundo o olisipógrafo Pastor de Macedo, permaneceram temporariamente noutros locais - ao Rego e na Calçada de Santo André (Macedo 1942:257) até se fixaram na Rua do Passadiço, no convento que pertencera às Carmelitas Descalças (alvará de 22 de Abril de 1775), e que passou a asilo exclusivo de Convertidas, com a designação de Real Recolhimento da Natividade de N. Sra. e Santa Maria Madalena da Rua do Passadiço.

Em 1805, problemas financeiros fizeram equacionar a venda do edifício (ANTT, Chancelaria D. Maria I, Liv. 71, fl. 316 v), mas ficou sem efeito, evoluindo o estado de degradação. Em 1809, a Regente D. Maria da Graça Fortunata Cré de Sena queixava-se do estado de miséria da instituição, que atribuía à ausência de Provedor que "sempre fora nomeado por aviso régio" (ANTT, Ministério do Reino, Recolhimentos, cx. 109, ms. 982, s.p.). O afastamento do anterior, o conde de Caparica, expusera o recolhimento a "graves prejuízos temporais e espirituais" (id.), faltando-lhes os recursos para sobreviverem. As centenárias rendas dos vários almoxarifados estavam obsoletas e as recolhidas viviam de esmolas. A dimensão espiritual também sofrera um grande revés com a retirada do Santíssimo Sacramento da igreja, deixando a comunidade sem missa.

O parecer do Marquês de Borba (26 de Fevereiro de 1825) é dominado pela anotação do estado de precariedade, afirmando que as rendas se destinavam "ao parco sustento de dezassete recolhidas que ocupavam dezassete cubículos dos trinta e um que tem o edifício que necessita de obras para a sua conservação" (id.). 
Sobre a reorganização dos recolhimentos da capital que juntou algumas instituições, por vezes sem um estudo prévio, o parecer apontava os inconvenientes da coabitação no recolhimento de dois tipos distintos de recolhidas - as "Filhas da Caridade" com as "Convertidas da Capital" (ANTT, Ministério do Reino, Recolhimentos, 109, ms. 982, s.p.). Foi por isso desfavorável à sua incorporação, dadas as possibilidades de conflito e a contradição dos estatutos, o que tornava a reorganização impraticável.

Mas a questão não ficou por aqui muito tempo. Em 1839, após nova averiguação aos recolhimentos da capital, o relatório do secretário geral José António Lopes (ANTT, Ministério do Reino, Ms. 2078) propunha a sua extinção devido à falta de Provedor e ao estado de abandono "logo que o das filhas da caridade tenha administrador para onde deviam ir as suas três únicas recolhidas e quatro pensionistas"(id.).

Mas não terá sido ainda a extinção das Convertidas, pois numa nota escrita em 1841 expõe-se que, ao contrário dos tempos antigos, quando "[ [... ] muitas prostitutas se admitiam nesta casa, hoje porém nenhuma nela se admite e só ali existem huas quatro ou cinco, e já de avançada idade" (Cruz 1841: 215). A partir de 1851 transita para a Administração dos Recolhimentos da Capital e, em 1855, instalaram-se no edifício do recolhimento as recolhidas de Nossa Senhora da Encarnação e Carmo, provenientes de Rilhafoles, cujo convento fora libertado para instalação do Hospital dos Coléricos. A instituição daqui resultante ainda existia em 1878, e era mencionada no roteiro das ruas de Lisboa em 1890. Em 1902 designava-se de N. Sra. Da Conceição do Passadiço e fora até então sua Regente D. Francisca da Purificação Pinto (AHPL, correspondência vigários da vara e párocos 1900-1903, Ms. 108, n. $\left.{ }^{\circ} 136\right)$.

No final, não obstante o esforço de adaptação feito após o liberalismo, perdera o impacto social. E ainda que os desígnios que levaram à sua fundação perdurassem - prevenir ou conter a proliferação da prostituição - a instituição já não lhe dava resposta, servindo apenas de local de abrigo a velhas prostitutas da capital.

Entre outras experiências que visavam a regeneração de prostitutas, foi fundado por iniciativa do tenente coronel João Luiz de Moura, governador civil de Lisboa, do major da polícia Ferreira do Amaral e do padre José Ferreira Governo, o Instituto de Santa Maria Madalena, em 1927, na travessa da Luz "para remediar ou atenuar a falta que fazia em Lisboa" (Macedo, 1942: 257-258) uma casa mantida pela caridade particular e por subsídios da assistência pública.

\section{III}

O edificado dos recolhimentos já estudados para Lisboa, memoriado ou sobrevivente e adaptado a novos usos, apresenta uma organização arquitetónica 
muito similar à conventual: espaços fechados sobre si, compostos por elementos construídos de contenção e clausura como a cerca, claustro, coro, grelha, confessionário, refeitório, dormitório, celas e cárcere. A Casa Pia das Convertidas de Lisboa, ao Loreto, encaixava quase integralmente neste modelo e integra o grupo dos que podem ser apenas memoriados.

A sua localização e delimitação geográfica ficaram inscritas no Tombo de Lisboa de 1756, quando o edifício já estava destruído e constava do elenco das propriedades desaparecidas ou danificadas pelo terramoto de 1755 .

Edificado entre a rua do Loreto, a rua das Chagas e a rua da Horta Seca (GEO, Tombo de Lisboa, 1756:fl. 67), a configuração arquitetónica, posterior a $1610^{8}$, consta da "Memória Histórica" feita pelo Provedor, por indicação de D. João V, c. 1730, que descreve não só o edifício, como relata a história da casa e as principais regras que a regeram. $\mathrm{O}$ rei, sensibilizado pelo estado de ruína da igreja e do recolhimento, patrocinou uma campanha de obras entre 1737 e 1744, sob direção inicial do arquiteto Custódio Vieira e finalizada por Manuel Vicente, mas cuja configuração desconhecemos (cf. ANTT, Minist. Reino, Recolhimentos, cx. 1101, mç. 983, s.p.).

A "Memória" descreve pormenorizadamente o interior do edifício, composto por dois pisos, a igreja e anexos e o claustro. Ultrapassada a porta principal pela rua do Loreto, a primeira divisão era dominada pelos elementos de comunicação com o exterior, o locutório e a roda, ficando-lhe contíguos os aposentos da Regente. Estes tinham acesso ao claustro e dispunham de uma capela privada, com altar, quadros e um painel de iconografia religiosa. A Regente tinha exclusividade de circulação por um corredor no piso superior, entre os dormitórios e a casa de lavor, ladeado de janelas que lhe permitiam observar a rua de um lado e os trabalhos manuais das recolhidas, do outro.

$\mathrm{Na}$ entrada principal, no patamar, de um lado seguia um corredor que conduzia aos cárceres e no lado oposto estavam as estruturas utilitárias e de suporte: a enfermaria, a casa do lavatório, a cozinha e o refeitório. $O$ teto deste tinha três arcos e dispunha de um púlpito de onde se liam histórias de santas enquanto decorria a refeição. Na parede, entre as janelas altas e gradeadas de ferro, que davam para o exterior, para o claustro e outra para a rua, estava um painel da "Ceia do Senhor".

Voltando ao patamar, uma escada de dois lanços ligava ao piso superior, onde havia uma espécie de espaço de evasão controlada "uma formosa janela sobre a porta da portaria com grade de ferro e rota [onde] costumam ir aos domingos de tarde espairecer estando nos restantes dias fechada à chave" (Id., fl. 193v).

8 Em 1610, a Câmara comparticipou no pagamento do edifício, contribuindo com 120 mil réis do dinheiro do real da água. A escritura só foi realizada em 1633. 
Localizavam-se aqui os dois dormitórios, para convertidas e porcionistas, o que o distinguia de outras casas de recolhidas, que possuíam celas individuais. Era também o espaço de trabalho e da aprendizagem, das artes manuais e da doutrina. A casa de lavor tinha janelas e varandas viradas para uma vinha e comunicavam com o dormitório, a secreta e os espaços de arrumação, onde estavam guardados os bens das recolhidas.

O claustro, circundado de colunas de pedra e grades, onde assentavam as varandas dos dormitórios e da casa de lavor, tinha árvores de pomar, a botica, uma fonte, que era semanalmente abastecida por criados das cavalariças reais, e outros elementos indispensáveis à auto suficiência da Casa - nora, atafona, forno e local dos despejos (cf. BNL, Memórias, fl. 191v).

A igreja ficava na parte sul do recolhimento, com porta para a rua da Horta Seca. O acesso entre esta e o recolhimento era feito pelo confessionário, cuja chave estava na posse da Regente e da confraria. Era composta por uma nave e duas capelas laterais votivas à Crucificação e a N. S. da Natividade, com retábulos de talha dourada e "bons ornamentos" (Id., fl. 194v). O altar-mor dispunha de uma tribuna onde estava exposto o Santíssimo Sacramento, ladeado por Sto. António e Sta. Maria Madalena.

O coro alto era gradeado, possuía altar e três tribunas fechadas para a capela-mor e "em domingo da Santíssima Trindade de 1658, ouviam missa na tribuna das recolhidas, junto à capela mor" (ANTT, Inquisição de Lisboa, Proc. 557, fl. 28). A comunhão das recolhidas fazia-se por uma fresta, só aberta para o sacramento. Na sacristia, sobreposta por arcos com afixação das armas reais, reunia a Mesa todos os domingos, onde tratava dos despachos da Casa.

Para a administração e governo interno do Recolhimento da Natividade de Nossa Senhora e Santa Maria Madalena, a Mesa da confraria regulou-se pelo regimento que mandou vir de Castela: "um auto de pasta preta dourado e gravemente escrito que ofereceram a el rei Filpe $1^{\circ}[\ldots]$ tomando-o debaixo da sua proteção real” (BNL, Memórias, fl. 99), confirmado por alvará de 6 de Março de 1592.

O "Compromisso da Administração da Casa da Piedade das Penitentes de Lisboa" é um conjunto de normas, em quinze capítulos, que desde os finais do séc. XVI regulou a vida da instituição. À semelhança de outros recolhimentos, foi reformado e adaptado às novas realidades, de que resultou um documento normativo no séc. XVIII, intitulado "Estatutos que hão-de guardar as irmãs recolhidas em a casa da gloriosa e penitente Maria Madalena". Em doze capítulos esboça a regulação quotidiana da Casa, acrescentando, corrigindo e consolidando alguns artigos do primeiro.

A vida religiosa e as obrigações quotidianas e de dias santos é abordada nos quinze capítulos do "Compromisso da Administração ... ", tratando de temas que vão da confissão aos procedimentos relacionados com a morte. Cinco capí- 
tulos são dedicados à administração financeira, descreve a finalidade do Cartório e a sua composição. Traça o perfil dos cargos externos e internos. Na última parte formula as diretivas de comportamento quotidiano quanto ao vestuário, os comportamentos a adotar no dormitório, o desempenho nas tarefas de rotina e finaliza com a tipologia de castigos. Sobretudo nas ultimas matérias, que tocam à interpretação da regulação quotidiana do recolhimento, os "Estatutos que hão-de guardar as irmãs ..." são mais esclarecedores. Aprofundam questões relacionadas também com a normalização do vestuário, a adoção de comportamentos no refeitório, no dormitório e em convívio; regulamenta o tratamento na doença e conclui com uma dissertação sobre a importância da clausura.

No seu conjunto, os estatutos consubstanciam as normas de funcionamento do recolhimento e os preceitos a que as mulheres estavam sujeitas (Araújo, 2015:128). Definem minuciosamente a vida da instituição, desde a administração e os oficiais nela envolvidos: o Provedor, o número de irmãos, tesoureiro, escrivão, solicitador e o sacerdote responsável pela administração espiritual da casa. $\mathrm{O}$ estatuto social exigido a cada um dos cargos, o Provedor por exemplo devia ser um "fidalgo de limpo sangue, de tal virtude e autoridade que o rei e principais e prelados e os grandes do reino" também fossem motivados a dotar a obra (AHSCML, Compromisso da Administração da Casa da Piedade das Penitentes de Lisboa, Capítulo dos Oficiais que hão-de Administrar esta casa, Tit. 1).

A Mesa era eleita anualmente, em presença de importantes dignitários ${ }^{9} \mathrm{e}$ assistida pela Companhia de Jesus, que dispunha de autoridade decretória nos assuntos da confraria, bem como a orientação espiritual e religiosa.

Entre as responsabilidades de administração da Mesa, contam-se a custódia dos livros com as determinações do governo da Casa - eleições, admissão de recolhidas, realização de casamentos, preparação das embarcações para o Brasil e Angola e assuntos da área administrativa e financeira ${ }^{10}$. A Mesa contava com um solicitador e um andador para a resolução dos assuntos exteriores ${ }^{11}$. A escolha dos cargos de serviço à casa era também da sua responsabilidade: o capelão, o advogado, o comprador e todos os que concorriam para a manutenção do recolhimento, como o aguadeiro e a criada para o serviço externo. $\mathrm{O}$ físico e o cirurgião e barbeiro pertenciam à Casa Real.

\footnotetext{
9 A 8 de Setembro, dia do nascimento de N. Sra. era feito um rol a partir do livro das esmolas e confrades da casa, que era entregue ao andador. Este chamava os irmãos e as pessoas para votar: o arcebispo de Lisboa, os priores dos mosteiros, irmãos da casa e o prepósito de S. Roque deviam estar presentes nesse dia.

10 Livros das recolhidas que foram servir, das que foram entregues a pessoas honestas; das embarcações que levaram mulheres para fora do reino; do depósito de bens; da receita e da despesa do tesoureiro; dos Acórdãos da Mesa; das Cartas e Provisões e resposta para fora do reino; dos irmãos e dos confrades e respetivas esmolas.

11 Trajava um vestido de pano com a insígnia de Madalena em penitência, com um crucifixo bordado em prata rodeado pela frase dit exit multum".
} 
Competia-lhe também a eleição e admissão das oficiais que integravam a clausura, todas recolhidas, à exceção da Regente e da porteira - duas oficiais responsáveis pela doutrina, uma oficial que ensinava lavores e outra oficial responsável pela área doméstica.

A eleição da Regente era precedida pelo escrutínio de pessoas "religiosas e virtuosas". Devia ser mulher nobre e honrada, embora de "condição branda para a consolação das penitentes" (AHSCML, Compromisso da Administração da Casa da Piedade das Penitentes de Lisboa, Capítulo dos Oficiais que hão-de Administrar esta casa, Tit. 1), pois pertencia-lhe o governo da casa: “[...] será de portas adentro a principal pessoa desta casa. Tomam como mãe e como a tal obedecerão em tudo" (BA, Regimento, cap. I, fl. 1). Devia pois supervisionar em permanência e ser o garante do equilíbrio da comunidade "não consentirá que haja bandos ou mexericos" (AHSCML, Compromisso, Do Ofício da Regente, Tit. 2, s.p.).

A estrita observância das normas, que cumpria e fazia cumprir (Araújo 2015:130), era apoiada no eficaz desempenho das restantes oficiais, que a auxiliavam na vigilância do trabalho, da limpeza da casa e do comportamento das recolhidas, garantindo a obediência e a clausura. Estrutura de comando que se verifica na maioria dos recolhimentos, quer seja no de Lisboa, no das convertidas de Braga ou no de S. Manços, só para citar alguns. Como afirma Liberato, sob a autoridade da Regente, os dias das recolhidas eram marcados pelos ritmos de trabalho e vivência religiosa, isoladas do mundo e da sua contaminação moral até que o casamento, a chegada dos maridos, o limite de tempo ou idade ditassem a sua saída (Liberato 2015:277).

A porteira possuía as chaves das portas, das janelas e da roda, que fechava "em tangendo as ave marias" (BA, Regimento, Do Ofício da Porteira, Tit. 7), entregando-as à Regente e novamente as abria pela manhã. Garantia a clausura e vigiava a comunicação, regrada e obrigatória com o exterior: para o abastecimento de mantimentos, a circulação de correspondência e o contacto, consentido superiormente, das recolhidas pelo ralo. As comunicações privadas com o exterior eram muito limitadas, estando esta norma muito presente nos regulamentos de outros recolhimentos. No de S. Manços, por exemplo, a correspondência estava também sujeita à atividade censória da Regente (Liberato 2004:287). A porteira devia permanecer na casa da roda e, na sua ausência, o locutório era encerrado. A entrada de estranhos na clausura só era permitida nas situações que exigissem a presença do padre confessor ou do médico, e acompanhados pela Regente e enfermeira, com aviso prévio às recolhidas para se resguardarem (BA, Regimento, cap. $12^{\circ}$, fl. 10).

A doutrina cristã era um aspeto elementar do processo de reforma, baseando-se o seu ensino numa cartilha, ministrada por duas recolhidas habilitadas. O mesmo se passava com o ensino de lavores, outra etapa fundamental para a regeneração. A aquisição das competências domésticas e manuais pertencia no 
séc. XVIII ao domínio da vigária (cf. BNL, Memórias, fls. 193, 201), coadjuvada na casa de lavor pela roqueira. Esta oficial tinha a responsabilidade de preparar, distribuir e acondicionar os materiais de trabalho que consistiam em linho, massarocas, meadas, novelos e fusos.

$O$ recolhimento tinha uma enfermaria, que estava sob a responsabilidade da recolhida enfermeira, auxiliada por uma ajudante da cozinha. Sob a supervisão do médico, aplicavam os tratamentos e adequavam a alimentação e o horário às doenças em curso (AHSCML, Compromisso, Da Enfermeira, $1^{\circ}$ tit.).

A escolha da despenseira, também recolhida, dependia do carácter e de reconhecidas capacidades de gestão. Geria a lista de doentes, os mantimentos necessários para o uso diário e a manutenção da despensa quanto ao provimento de lenha, carvão e água. Competia-lhe também supervisionar a cozinha (Id., Da Despenseira, $1^{\circ}$ tit.).

A terceira parte do Compromisso trata do processo de admissão, elencando as características necessárias e aquelas que ditavam a exclusão. Não obstante a abrangência do quadro teórico que norteava esta questão, um parecer do jesuíta Francisco Soares defendia o recolhimento arbitrário de mulheres com comportamentos impróprios, desde que com aval régio (ANTT, Armário Jesuítico, Livro 8, fl. 478).

De facto, conforme exemplificam alguns relatos das Cartas Jesuíticas de 1588 , por exemplo, em que "hum padre acabou com huma mulher de ma vida se metesse nas convertidas e deixou o mao estado em que andava" (cit. Brockey 2006:10), indicia que o processo de admissão era pensado como uma situação temporária, que visava formar para reintegrar na sociedade. E nessa formação prevalecia a vertente religiosa e educativa para a vida doméstica (Reis, 2004:267).

O recolhimento tinha capacidade para trinta mulheres, cujos comportamentos fossem socialmente reprováveis - prostituição, relações ilegítimas e contexto familiar instável, que pretendessem reabilitar-se, havendo também relatos de fuga a violência doméstica. Só podia acolher "as [que] as rendas e esmolas da casa possam sustentar comodamente" (AHSCML, Compromisso,70 tit.).

Havia predisposição para receber mulheres mais jovens e bonitas, não só porque eram mais suscetíveis de entrar na prostituição, como também teriam acesso facilitado ao casamento. Podiam ser adotadas medidas temporárias, em casos secretos e de mulheres fugitivas, para as quais se procuravam alternativas junto das famílias.

O ingresso dependia também de outras questões religiosas, legais e sociais. Como fatores de exclusão surgiam as prostitutas "infames e vis que estão nos lugares públicos” (id., $10^{\circ}$ tit.) devido ao perigo de instabilidade interna; as questões relacionadas com a fé e a justiça, com culpa da fé ou de feitiçaria, ser alcoviteira ou portadora de uma doença contagiosa; ter dívidas, ter culpa de adúltera ou de outro crime sujeito a prisão. 
O processo de admissão começava pela proposta entregue na Mesa, que a avaliava, recorrendo às áreas de influência pessoal e residencial da candidata, onde se apurava se reunia as necessárias condições. Era feita uma biografia e após aceitação e período probatório ${ }^{12}$ entrava na clausura, os seus bens pessoais eram inventariados e guardados e finalmente eram avaliadas as competências pessoais quanto a artes manuais e ao serviço doméstico. Finalmente, era-lhe atribuída a tarefa mais adequada às suas aptidões.

Desconhece-se para Lisboa o ritual de entrada, bem documentado noutros recolhimentos, podendo deduzir-se algumas semelhanças. Por exemplo, nas Convertidas de Braga, a entrada era precedida de confissão e comunhão, recebendo então o hábito pela mão da Regente (Araújo 2004:135).

A semelhança entre conventos e recolhimentos é também notória na entrada de freiras e recolhidas na clausura: o cumprimento de uma vida claustral, o afastamento do mundo e da esfera pública com o objetivo de protege-las, puni-las ou purificá-las (Fernandes 2013:5).

No universo dos recolhimentos femininos do período Moderno há um conjunto de circunstâncias que é análogo - o trabalho e a aquisição de competências domésticas e de lavores, encaradas como preparatórias para a vida e para boa gestão familiar, como recurso para a autonomia e capacidade de sustento; mas também as rotinas, o vestuário, ou a alimentação.

Outra circunstância transversal nestas instituições, era a subordinação a uma severa disciplina e a constante vigilância (id.), imperando na clausura o silêncio, a oração e a obediência - etapas consideradas fundamentais para a regeneração da mulher penitente.

Sendo a principal missão da Casa das Convertidas a formação da penitente para um futuro reingresso na comunidade e assumir um papel social conveniente ao bem comum, com ênfase no atrás descrito, tornava-se indispensável o conhecimento da doutrina cristã ${ }^{13}$.

E a doutrinação baseava-se em preceitos, alguns quotidianos, de oração mental e vocal, de confissão e comunhão, de jejum e a disciplina, de silêncio e o capítulo das culpas.

O calendário da fé presidia no interior da instituição, a par da assiduidade da confissão e da comunhão. A oração e a missa, diária e em dias de festa, representavam um dos pilares e era assegurada pelo capelão. Contrariamente ao sacerdote das recolhidas de Braga, por exemplo, que devia ir à instituição sempre que era chamado (Araújo 2004:135), o das Convertidas de Lisboa tinha obrigação

\footnotetext{
12 A regente recolhia a pretendente numa casa separada, tomavam informações e na $4 .{ }^{\text {a }}$ feira seguinte, "como era estilo", era recolhida em clausura.

13 As orações a saber eram: o Pai Nosso, Avé Maria, Credo, Salvé Rainha, os Mandamentos, a definição de Santíssima Trindade.
} 
de permanecer todas as manhãs na igreja. A prática espiritual e a pregação por outros sacerdotes era aceite nos estatutos e, na ausência de culto, faziam-se leituras de livros devotos.

A música era uma aptidão cultivada nas Convertidas, também considerada um meio de "descuidarem-se de seus cuidados" (BNL, Memória, fl. 201), aproveitando-se as melhores vozes que, acompanhadas ao som de rabecão, órgão ou cravo, participavam na entoação das missas de domingo e da semana santa.

O plano de reabilitação incluía o jejum e a disciplina "castigar os pecados da carne com a mortificação dela que esta seja a mezinha” (BA, Regimento, Cap. $5^{\circ}$, fl. 5v).

Enaltecia-se o silêncio na clausura, só devendo comunicar-se "senão mui manso sem serem ouvidas das que perto estiverem" (id., Cap. $6^{\circ}$, fl. 6 ), recriminando-se até a elevação da voz que pudesse ser ouvida na rua (id.).

$\mathrm{O}$ quotidiano era regido sob rigoroso horário, que previa horas de recreio e repouso, intercalado por exercícios religiosos e a quase constância da oração, mental e vocal. O combate ao ócio era um dos pilares fundamentais destas casas que deviam manter as mulheres permanentemente ocupadas (Araújo 2004:142).

A rotina começava ao amanhecer, despertando a comunidade no verão às cinco e no inverno às sete horas. À arrumação do dormitório, seguia-se uma primeira deslocação ao oratório. $O$ plano de reabilitação contemplava o desempenho de todas as tarefas domésticas, da limpeza da casa e das roupas à preparação dos alimentos, ficando assim habilitadas a dirigir uma casa e uma família (AHSCML, Compromisso, Capítulo Da ocupação e da ordem do trabalho, $1^{\circ}$ tit.).

Concluídas as tarefas, faziam a primeira refeição, às dez horas no verão, às onze no inverno e nos dias de jejum ao meio-dia. Regressavam novamente ao oratório, seguia-se um espaço de recreação sempre sob vigilância, sendo recomendadas apenas conversas e práticas insuspeitas. Proibiam-se quaisquer expressões de convívio mundano como risos, cantigas, confidências, considerados prejudiciais à comunidade e por isso sujeitos a castigos, sobretudo quando se tratava de agressões físicas e verbais, incluindo maledicência sobre o passado (id., Cap. 10, fl. 9v).

A etapa seguinte era ocupada em tarefas rotineiras da casa ou na casa de lavor, onde simultaneamente prosseguia a formação espiritual, através da leitura de livros de ações espirituais. Desta forma prevenia-se a ociosidade e em resultado dessa aprendizagem ainda se produziam peças que contribuíam para a subsistência da comunidade ${ }^{14}$ (AHSCML, Cap. De Como se hão de receber as mulheres que arrependidas de seus pecados se quiserem recolher nela, $13^{\circ}$ tit.).

14 As peças quando concluídas eram entregues ao Tesoureiro da casa, que recolhia o pano no armário do cartório. Dele se faziam lençóis, roupa para o serviço da casa e outra que se repartiam pelos pobres. 
Havia outra oração ao entardecer, durante uma hora, seguida de breve pausa para conversa e fazia-se a última refeição do dia, às sete horas no verão e uma hora mais tarde no inverno. Regressavam ao oratório antes de dormir (ANTT, Inquisição de Lisboa, Proc. 557, fl. 76) e daí para o dormitório, às nove horas no verão e no inverno às dez. Havia um ritual de aspersão de água benta nas camas e uma última oração, fechando-se a porta à chave e impondo-se o silêncio até ao dia seguinte.

Este espaço era objeto de vigilância contínua, dormindo a Regente na cabeceira do dormitório e a vigária e a porteira, noutros lugares estratégicos. Certificavam-se que não partilhavam a cama, trocando de lugar todas as semanas, sob pena de severo castigo.

O conceito de privado não existia aqui, permanecendo uma lâmpada acesa toda a noite para dissuadir qualquer infração "deverão estar compostas toda a noite como quem tem sempre ante si a Deus" (BA, Regulamento, Cap. 10, fl. $8 \mathrm{v}$ ). A vigilância devia-se à conceção do corpo como fonte de pecado, estando interditos quaisquer contactos físicos entre as convertidas, consideradas mais suscetíveis ao pecado carnal e à voluptuosidade.

Os regulamentos sobre o vestuário anulavam quaisquer resquícios de individualidade e de vaidade. $\mathrm{O}$ uso de roupas próprias era permitido, mas sobreposto pelo hábito de N. Sra. do Monte do Carmo, pelo menos no séc. XVIII, podendo ainda usar capelo comprido quando as temperaturas eram mais baixas.

A importância de cortar com o mundo anterior surge em regras como a proibição de uso de sedas, na regulamentação dos toucados, linho ou holanda branca, o calçado deveria ser preto de "sapata de soleta e chapins serrados ou abertos" (BA, Regimento, cap. $8^{\circ}$, fl. 8). As proibições expressam essa rutura, não podiam usar "toalhas assafroadas ou com outras supérfluas galanterias, nem usar de posturas no rosto". A questão dos véus assafroados remonta às cortes de 14811482, quando se determinou que as prostitutas deveriam trajar distintamente das outras mulheres "que andem em corpo e sem chapins, com veos açafroados para que sejam distinguidas das mulheres honestas" (cit. Aguiar 1947:465), associando-se às disposições castelhanas sobre prostitutas, obrigadas a usar um penteado cor de açafrão com um pente elevado.

As refeições decorriam conforme o regulamento, reunindo-se no refeitório ao toque da campainha. Após a bênção da mesa, sentavam-se pela ordem indicada pela Regente e a refeição era acompanhada por uma leitura piedosa (BA, Regimento, Cap. 9o, fl. 8v.).

A dieta alimentar era composta de carne e jejum ou peixe às sextas-feiras. Comparando as ementas constantes de um rol de despesas de 1652, com as ementas da "Memória Histórica" de 1730, não se encontram grandes alterações na sua dieta. Em 1672 recebiam a quantidade para sete dias e era composta por meio litro de azeite, pão e seis rações de carneiro ou de galinha, nove rações de 
porco e carvão para o seu processamento. Em 1730, recebiam diariamente dois pães, meio arrátel de carne e à noite dois ovos ou o correspondente em dinheiro para a ceia.

A alteração a esta dieta era permitida somente nos dias de festa, consumindo então arroz ou cuscus, fruta, "um marram na festa de Natal, um carneiro na Páscoa, na Quaresma um saco de legumes e uma arroba de bacalhau em dia de S. João" (BNL, Memória, fl. 201 v).

A violência não sendo comum, existia. Estavam proibidas quaisquer dinâmicas que a potenciassem. Na confissão, pública ou privada, por exemplo, proibiam-se as "historias alheas de aquele lugar e juntamente não se acusem de modo a descobrir os nomes das pessoas, ou pecados alheios" (BA, Regimento, Cap. $4^{\circ}$, fl. 5).

O quotidiano podia ser marcado por momentos de grande tensão, com violência verbal e física conforme relatos para a Casa de Santa Maria Madalena, em Braga, onde o incumprimento dos estatutos dava lugar, primeiro a admoestação por palavras, valendo a reincidência a ida para o Tronco (Araújo 2004:129). Na casa das Convertidas de Lisboa, existiam cárceres, mas desconhecemos quais as faltas que levavam à aplicação dessa medida. A medida máxima contra faltas cometidas por recolhidas era, no caso de Braga, comunicado ao arcebispo e no caso de Lisboa, ao Provedor.

Nas Convertidas de Lisboa, a gestão do conflito tinha enquadramento normativo no capítulo "das culpas", que previa uma reunião semanal para exteriorização dos delitos, através da confissão em comunidade. Julgava-se que este método diminuía a tensão no grupo e contribuía para a "quietação da casa e reformação dos costumes". Era o espaço onde se expunham as culpas e as queixas e onde se procurava a reconciliação.

No recolhimento das Convertidas de Braga, uma metodologia similar era desempenhada pela zeladora, um cargo intermédio entre a Regente e as recolhidas, que tinha a tarefa de publicitar as faltas e o incumprimento dos estatutos, assumindo uma função pedagógica (Araújo 2014:133).

O processo inquisitorial de Joana da Cruz, porteira das Convertidas elucida sobre a dinâmica do espaço, o conflito e a sua gestão. Denunciada à Inquisição pelo capelão da Casa, os testemunhos contra ela foram-se sucedendo ao longo do processo, que traça um quadro vivo do quotidiano. Não seria normal, nem representativo, mas distancia-se bastante do que estava regulamentado como, por exemplo, nos momentos da oração matinal que também serviam para socializar "estava em oração, muito enlevada. Perguntou-lhe o que tinha ao que ela disse que estava em grande sentimento [...]. Falava publicamente em presença de muitas mulheres desta casa" (ANTT, Inquisição de Lisboa, Proc. 557, fl. 42 v.). 
Este episódio precipitou-se em conflito "afrontava as companheiras com nomes afrontosos e que nenhuma lhes chegava ao seu chapim" (ANTT, Inquisição de Lisboa, Proc. 557, fl. 29). Contém relatos de agressão, ferimentos e aplicação do castigo e transferência para o recolhimento da Conceição dos Cardais (id.). Como já foi referido, a severidade dos castigos era proporcional à culpa, variando da inibição de comer e, como neste caso, a entrega do caso ao Provedor, que a transferiu para outro recolhimento.

No seu longo percurso institucional, algumas crises mais severas afetaram o funcionamento da instituição e levaram à tomada de decisões não regulamentadas. O Provedor conde de S. João, perante uma conjuntura de instabilidade económica a que se associaram alguns comportamentos ilícitos, indagou o rei e os jesuítas, em 1631, se o elevado número de recolhidas num período económico difícil, conjugado com a falta de observância das convertidas, justificavam "aliviar a casa de alguma desta gente" (ANTT, Armário Jesuítico, Livro 8, fl. 478). O parecer dos jesuítas relembrou que era obrigação do Provedor cuidar dos interesses do recolhimento e contribuir para a sua subsistência. No entanto, se a comunidade estava instável, era admissível "aliviar de algumas pessoas das que tem sem escrúpulo ainda que elas hajam de tornar ao estado antigo porque [... ] visto nam se alcançar o conserto da sua emenda, antes a sua estada é com danos de outras" (id.).

Desaconselhava a licença geral devido ao perigo de abandono massivo do programa de regeneração, propondo um período de reflexão para as mais "inquietas". Se o problema persistisse, justificava-se a saída ou a expulsão (id.). E quanto à questão das dificuldades financeiras, sobre a insuficiência dos rendimentos régios (Governo, 1633, fl. 32, Biblioteca da Ajuda, 51-VI-7), apontava Filipe III que o recolhimento das penitentes fora sempre muito favorecido pelos reis precedentes (Governo, 1632, fl. 8, Biblioteca da Ajuda, 51-VI-4).

A estadia na Casa das Convertidas terminava com a reabilitação da recolhida e o restabelecimento do contacto com o mundo exterior. É o tema da quarta parte do Compromisso, iniciando-se assim o processo de procurar "remédio" para as suas vidas, que era da responsabilidade do Provedor e irmãos da Mesa.

O casamento era a solução mais plausível e era encarado como um remédio e o marido o seu sustentáculo, quer fosse no reino ou nas conquistas. Se o recolhimento fora motivado devido a uma relação com um homem, dava-se preferência ao casamento de ambos. A Misericórdia atribuía às Convertidas dois dotes anuais, na primeira metade do século XVIII, de um legado de Afonso Dias de Medina (BNL, Memória, fl. 207 v).

Periodicamente eram enviadas convertidas para a Índia, Brasil e Angola, realizando-se a cerimónia previamente na igreja do Recolhimento, em presença do Provedor e mediante assinatura de um termo pelas partes. A título de exem- 
plo, em 1609 foram enviadas catorze convertidas; Em 1620 o Provedor pedia ao conselho da Índia, uma mercê régia de mantimentos, para a embarcação e um subsídio para vestuário para dez recolhidas que pretendia enviar para o Maranhão (códice 32, fl. 32, AHU) e em 1632 foram seis.

Outras alternativas eram o serviço doméstico, onde aplicariam as competências adquiridas no recolhimento, inclusive ao serviço de casas nobres (AHSCML, Compromisso, Prólogo). Foi também usual, funcionando quase como uma obra pia, pelo menos no século XVI, a atribuição a um homem casado e idóneo de uma recolhida a quem arranjaria casamento num determinado período de tempo, durante o qual lhe pagaria uma remuneração que completaria o seu dote (id., Cap. Do remédio das Mulheres Recolhidas, $3^{\circ}$ tit.).

Além da família, do casamento ou do serviço numa casa, era possível a emancipação, sustentando-se com o fruto do seu trabalho, em companhia de mulheres virtuosas e aprovadas pela mesa (id., $4^{\circ}$ tit.). Outra opção, que também implicava a existência de um dote, era a tomada de votos. O auxílio da mesa neste caso consistia na procura de um mosteiro para professar, sendo esta via muito escrutinada e com o parecer do confessor da pretendente.

Esta opção era automática por exemplo nas recolhidas da Casa Pia de Aporbation, em Valladolid, que usufruindo da articulação com o convento de $\mathrm{S}$. Filipe da Penitência, após o processo de conversão que durava um ano, permitia às que o desejassem a passagem para o convento de S. Filipe da Penitência, abraçando a vida religiosa (http://revistaseug.ugr.es/index.php/cnova/article/ view/2577/2727).

A morte em clausura foi para algumas a etapa final, sendo também esta matéria regulada no "Compromisso" e descrita na "Memória Histórica".

Toda a comunidade se mobilizava, começando o ritual com a participação do capelão ou de um padre da Companhia "para ajudar no trânsito", e de todas as convertidas que no coro a encomendavam a Deus, permanecendo apenas um irmão da Mesa na portaria.

A convertida era amortalhada num hábito e era velada "sobre uma alcatifa com quatro luzes e caldeira de água benta que lhe lançarão as irmãs porcionistas" (BNL, Memória, fl. 203 v). Rodeado o quarto de velas, os irmãos da Mesa colocavam o corpo no esquife coberto e transportavam-no para a igreja, enquanto outros acompanhavam com tochas, seguindo o capelão e o cura que rezavam responsos. Saiam pela portaria em procissão até à igreja onde era enterrada com solenidade.

Esta acabava por ser também uma representação, edificante para a comunidade e para a população, testemunhando a graça de uma boa passagem, envolta em símbolos e cumprindo todos os requisitos de uma "boa morte". 


\section{Considerações Finais}

Se procurarmos dimensionar a eficiência da Casa Pia das Convertidas de Lisboa nas proposições que estiveram na sua génese - retirar da sociedade e regenerar mulheres em situação de prostituição ou em perigo devido a exclusão familiar e matrimonial -, tendemos a considerá-la como uma instituição que cumpriu o seu papel e serviu objetivos sociais apreciáveis até ao advento do liberalismo. Foi certamente insuficiente para debelar um problema profundo da sociedade de Lisboa, conforme se observa pela continuidade legislativa e na expressividade dos números. Mas a sua proposta não era a de suprimir a prostituição, mas sim a de acolher e reabilitar.

Essa etapa implicava renúncia ao mundo e sujeição a um novo universo social e mental, cuja vida dentro de portas decorria sob os princípios da clausura, do silêncio, da obediência, entregues à ordenação do trabalho, da aprendizagem de lavores, à oração e sujeitas a normas de vestuário, alimentação e comportamento, até ao culminar do programa de conversão.

A instituição comprometeu-se com a moralização e regularização das relações afetivas, promovendo o casamento, envolvendo-se também no acolhimento e regeneração de mulheres provenientes de ligações ilegítimas e jovens e meninas retiradas de contextos familiares promíscuos e de violência doméstica.

Desde os seus primórdios em 1543, do Recolhimento das Penitentes Arrependidas, sob a alçada da Confraria da Paixão de Cristo, saíram recolhidas, dotadas e direcionadas pelo casamento, muitas delas para o projeto da expansão ultramarina para a Índia, Brasil, e também para Angola e Moçambique. Poderá esta linha ser aprofundada e, noutra etapa, constituir per si um estudo, construído a partir das suas histórias de vida e acompanhamento de percursos pessoais, procurando simultaneamente avaliar a dimensão que obtiveram no projeto ultramarino.

A proteção régia, alguma adaptação às solicitações que a sociedade, em mudança, lhe foi exigindo e a tradição sustentaram-lhe a continuidade até ao alvor do séc. XX.

\section{Bibliografia e Fontes}

\section{Siglas}

AHSCML - Arquivo Histórico da Santa Casa da Misericórdia de Lisboa ANTT - Arquivo Nacional da Torre do Tombo

BA - Biblioteca da Ajuda

BNL - Biblioteca Nacional de Lisboa 


\section{Manuscritos}

Arquivo Histórico da Santa Casa da Misericórdia de Lisboa, Provedoria dos Recolhimentos da Capital, Recolhimento do Passadiço, Compromisso da Administração da Casa da Piedade das Penitentes de Lisboa, 6 de março de 1592.

Arquivo Nacional da Torre do Tombo, Armário Jesuítico, Livro 8, fl. 478.

Arquivo Nacional da Torre do Tombo, Chancelaria D. Filipe I, Livro 3.

Arquivo Nacional da Torre do Tombo, Chancelaria D. João III, Livro 5, 35.

Arquivo Nacional da Torre do Tombo, Chancelaria D. Maria I, Livros 21, 71

Arquivo Nacional da Torre do Tombo, Inquisição de Lisboa, processo n. 557.

Arquivo Nacional da Torre do Tombo, Ministério do Reino, Livro 234, fl. 23.

Arquivo Nacional da Torre do Tombo, Ministério do Reino, Mesa da Consciência e Ordens, Recolhimentos, cx. 1101, mç. 983, s.p.

Biblioteca da Ajuda, Estatutos que hão-de guardar as irmãs recolhidas em a casa da gloriosa e penitente Maria Madalena, [sd]. BA 49-II-29

Biblioteca Nacional, Despesas, códice 11452.

Biblioteca Nacional (1730). Manuscrito Memórias Históricas do Recolhimento das Convertidas (da Natividade). cota F. 4640.

Gabinete de Estudos Olisiponenses (1769). Livro da Receita e Despesa da fazenda do Real Recolhimento de N. Sra. Natividade Casa Pia das Convertidas feito para se lançarem as cargas e descargas na conta do tesoureiro Marçal dos Santos de Abreu no ano que corre Do primeiro de janeiro de 1769 para findar em o ultimo de dezembro do dia em que é escrivão Francisco José Alvares de Afonseca. Ms. Lv. 32.

\section{Bibliografia}

AMBRÓSIO, António (1987). "D. Simoa de S. Tomé em Lisboa: o seu testamento e a sua capela”, Revista Municipal, S. 2, 21, 3-22.

AGUIAR, Asdrubal A. (1947). Rápido escorço da prostituição nas idades média e moderna em Portugal” sep. Revista "A Medicina Contemporânea”, Lisboa.

ARAÚJO, Maria Marta Lobo de (2015). “Um quotidiano marcado por regras: o primeiro regulamento do recolhimento de Santa Maria Madalena de Braga (século XVIII)”, Do Silêncio à Ribalta, 127-143.

BELO, Filomena (1988).“Os Recolhimentos Femininos e a Colonização”, Claro e Escuro, Revista de Estudos Barrocos. Quimera, 6-7, 123-136.

BROCKLEY, Liam M. (2006). "O Alcazar do CEO: The Professed House at Lisbon in 1588”, Archivum Historicum Societatis Iesu, 89-135.

CASTRO, João Baptista de, Mappa de Portugal antigo e moderno (1870). 3. ${ }^{\mathrm{a}}$ ed. revista e accrescentada, Typ. do Panorama.

COATES, Thimoty (1998). Degredados e Órfãs: colonização dirigida pela coroa no império português. 1550-1755. Lisboa: Comissão Nacional para as Comemorações dos Descobrimentos Portugueses, Lisboa. 
CONCEIÇÃO, Frei Apolinário da (1740). Claustro Franciscano erecto no domínio da coroa Portuguesa, e estabelecido sobre dezeseis venerabilissimas columnas. Expoem-se sua origem, e estado presente, a de seus conventos e mosteiros. annos de suas Fundações, numero de Hospicios, Prefeituras, Recolhimentos, Parochias, e Missoens, dos quaes se dá individual noticia, e do numero de seus Religiosos, Religiosas, Terceiros, e Terceiras, que vivem collegialmente, tanto em Portugal como em suas Conquistas, Lisboa: Off. De António Isidoro da Fonseca.

COSTA, António Carvalho (1712). Corografia portuguesa e descriçam topografica do famoso reino de Portugal. Lisboa : na Of. de Valentim da Costa Deslandes. Tomo III.

CRUZ, Francisco Inácio dos Santos (1841). Da Prostituição na Cidade de Lisboa. Typ. Lisbonnense.

FRANCO, António (1719).A imagem da virtude em noviciado da Companhia no Real Colégio de Jesus de Coimbra, Universidade de Coimbra.

FURTADO, Júnia Ferreira (1997), Desfilar: A Procissão Barroca. Revista Brasileira de História, 33, 251-279.

GABINETE DE ESTUDOS OLISIPONENSES. História dos mosteiros, conventos e casas religiosas de Lisboa na qual se dá notícia da fundação e fundadores das instituições religiosas (1950-72). Lisboa: Câmara Municipal.

LOPES, Maria Antónia (2010). Proteção social em Portugal na Idade Moderna: Guia de estudo e investigação. Imprensa da Universidade de Coimbra.

MACEDO, Luís Pastor de (1942).Lisboa de Lés-a-Lés, vol. III. Lisboa: CML.

MAGALHÃES, António (2012). Pouco importa ter sangue nobre e ser de procedimento vil: mulheres em conflito no Recolhimento de S. Tiago (século XVIII) , in Estudos Regionais, II Série, n. ${ }^{\circ}$ 6, pp. 133-154.

MARTINS, Maria Joana de Sousa Anjos (1961). Subsídios para o estudo da assistência social portuguesa: os recolhimentos de Lisboa: 1543-1623. Dissertação para a Licenciatura em Ciências Históricas e Filosóficas, apresentada à Faculdade de Letras da Universidade de Lisboa, Lisboa, [s.n.].

OLIVEIRA, Cristóvão Rodrigues de (1939). Sumário em que brevemente se contém algumas cousas, assim eclesiásticas como seculares, que há na cidade de Lisboa, pref. Augusto Vieira da Silva. Lisboa: 3. ${ }^{\text {a }}$ ed., [s.n.].

PEREIRA, Luís Gonzaga (1927). Monumentos Sacros de Lisboa em 1833. Lisboa.

REIS, Maria de Fátima Dias (2004). Poder Régio e tutela episcopal nas instituições de assistência na época moderna, os recolhimentos de Lisboa, in Igreja, Caridade e Assistência na P.I. (Séc. XVI-XVIII), CIDEHUS/EU, Edições Colibri, Lisboa.

SANT'ANA, José Pereira de, padre (1745-1751). Chronica dos Carmelitas da antiga, e regular observancia nestes Reynos de Portugal, Algarves e seus dominios, Lisboa: $\mathrm{Na}$ Officina dos Herdeiros de António Pedrozo.

SILVA, João Marques (1894). Tombo de Lisboa 1756, Ms-Lv. 4.

SILVA, José Justino de Andrade (1854). Collecção chronologica da legislação portugueza. Lisboa: Imprensa de J. J. A. Silva.

MACHADO, Carla Manuela Sousa (2014). Entre a clausura e o século: o recolhimento de Santo António do campo da Vinha sob a administração da Misericórdia de Braga (século XVII-XIII), Universidade do Minho, dis. de Mestrado policopiada, Braga. 


\section{Internet}

COELHO, António José, S.J. (2006).Cartas. Braga: Editorial A.O. http://www.jesuitas.pt/ Admin/Public/Download.aspx?file.... cartas-in\%C3\%A1cio.pdf (consultado em 1 de agosto de 2016).

ESPERANCA, Manuel da, O.F.M. (1586-1670). Historia Serafica da Ordem dos Frades Menores de S. Francisco na Provincia de Portugal. Lisboa: officina Craesbeeckiana. http://purl.pt/20706 (consultado em 3 de agosto de 2016).

MESTRE, Sílvia (2004). O Hospício de N. Sra. da Piedade de Évora: uma instituição assistencial pós-Tridentina. http://books.openedition.org/cidehus/210 (consultado em 7 de Janeiro de 2016).

Secretaria de Estado dos Negócios do Reino, livro 1839, Portaria de 5 de Agosto de 1839, http://legislacaoregia.parlamento.pt/V/1/20/17/p305 (consultado em 6 de setembro de 2016).

SOBREMAZAS, Ainhoa Fernández. Prostitutas en la España Moderna. Historia 16, 2006, n. ${ }^{\circ} \quad 357$, pp.8-37. file:///C:/Users/delminda/Downloads/Dialnet-InformeEspecial-1359011\%20(2).pdf (consultado em 12 de janeiro de 2016).

TELES, Baltasar(1645 - 1647). Crónica da Companhia de Jesus na Província de Portugal e do Que Fizeram nas Conquistas deste Reino os Religiosos que na mesma Província Entraram, nos Anos em Que Viveu Santo Inácio de Loiola. http://www.brasiliana.usp. $\mathrm{br} /$ handle/1918/01908110 (consultado em 5 de agosto de 2016). 